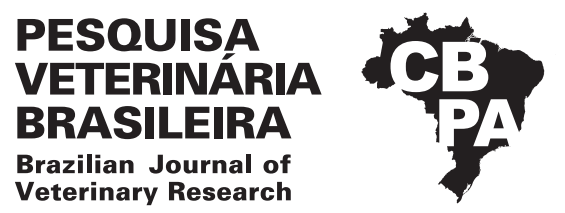

Pesq. Vet. Bras. 39(7):476-480, July 2019 DOI: 10.1590/1678-5150-PVB-6030

Original Article

ISSN 0100-736X (Print)

ISSN 1678-5150 (Online)

\title{
Diagnosis of Brachyspira pilosicoli, Brachyspira hyodysenteriae and Brachyspira intermedia in hens and laying hens in the western region of Paraná through bacterial isolation and identification in qPCR $^{1}$
}

\begin{abstract}
Thiago Goulart ${ }^{2}$, Leonardo Gruchouskei ${ }^{2}$ (D) , Jessica Gonçalves ${ }^{2}$, João Pedro Cavasin², Monica R. Matos² (D), Mayane Faccin² and Aline de M. Viott²*

ABSTRACT.- Goulart T., Gruchouskei L., Gonçalves J., Cavasin J.P., Matos M.R., Faccin M \& Viott A.M. 2019. Diagnosis of Brachyspira pilosicoli, Brachyspira hyodysenteriae and Brachyspira intermedia in hens and laying hens in the western region of Paraná through bacterial isolation and identification in qPCR. Pesquisa Veterinária Brasileira 39(7):476-480. Laboratório de Patologia Veterinária, Universidade Federal do Paraná, Setor Palotina, Av. Pioneiro 2153, Palotina, PR 85450-000, Brazil. E-mail: viott@ufpr.br

Bacteria of the genus Brachyspira can cause enteric diseases in poultry causing a decrease in productivity. The occurrence of this disease in chickens has already been verified in countries such as Australia, Italy, and the United States, but in Brazil, until now, epidemiological studies about Brachyspira sp. frequency were only carried out on pig farms. The objective of this study was to evaluate the presence of bacteria of the genus Brachyspira sp. through isolation and confirmation of the species Brachyspira pilosicoli, Brachyspira hyodysenteriae and Brachyspira intermedia using the qPCR technique. Samples from 110 hens aged from 35 to 82 weeks were collected, 40 were from commercial egg farms and 70 were from laying hens matrices. For the first evaluation, bacterial isolation was performed from the feces. Positive samples were submitted to qPCR to identify the three species proposed. Cecum fragments of the birds were collected and fixed in formaldehyde for histological evaluation and counting of goblet cells. Of the 110 samples, 48 characteristic isolates of Brachyspira (43.6\%) were obtained and of these in qPCR 13 identified as B. hyodysenteriae $(11.8 \%)$ and 5 all from the same farm as Brachyspira intermedia (4.5\%), 2 samples were positive for both agents (1.8\%) and 28 were not characterized by qPCR (25.5\%). None histopathological lesions were observed in the chicken cecum and no significant statistical difference was noticed in the count of goblet cells of the positive hens. It can be evidenced by the occurrence of Brachyspira sp. in laying farms and hens in Brazil, with special relevance to Brachyspira intermedia that can be potentially pathogenic for these animals.
\end{abstract}

INDEX TERMS: Brachyspira pilosicoli, Brachyspira hyodysenteriae, Brachyspira intermedia, hens, laying hens, Paraná, bacterial isolation, qPCR, commercial birds, frequency, enteropathogens, spirochetosis, bacterioses.

RESUMO.- [Diagnóstico de Brachyspira pilosicoli, Brachyspira hyodysenteriae e Brachyspira intermedia em aves de postura e matrizes de corte na região oeste do Paraná através do isolamento bacteriano e identificação na qPCR.] Bactérias do gênero Brachyspira podem ocasionar enfermidades

\footnotetext{
${ }^{1}$ Received on December 9, 2018.

Accepted for publication on January 31, 2019.

${ }^{2}$ Laboratório de Patologia Veterinária, Universidade Federal do Paraná (UFPR), Setor Palotina, Av. Pioneiro 2153, Palotina, PR 85450-000, Brazil. *Corresponding author: viott@ufpr.br
}

entéricas em aves acarretando a queda de produtividade. A ocorrência desta enfermidade em galinhas já foi verificada em países como a Austrália, Itália e Estados Unidos, porém no Brasil, até o momento, trabalhos epidemiológicos sobre a frequencia de Brachyspira sp. só foram realizados em granjas de suínos. 0 objetivo deste estudo foi avaliar a presença de bactérias do gênero Brachyspira sp. através do isolamento e confirmação das espécies Brachyspira pilosicoli, Brachyspira hyodysenteriae e Brachyspira intermedia utilizando a técnica de qPCR. Foram coletadas amostras de 110 aves com idade 
entre 35 e 82 semanas, sendo 40 de granjas de postura comercial e 70 de granjas de matrizes de corte. Para avaliação primeiramente procedeu-se o isolamento bacteriano a partir das fezes. As amostras positivas foram submetidas a qPCR para identificação das três espécies propostas. Fragmentos de ceco das aves foram coletados e fixados em formol para avaliação histológica e contagem de células caliciformes. Das 110 amostras foram obtidos 48 isolamentos característicos de Brachyspira $(43,6 \%)$ e destes na qPCR 13 identificadas como $B$. hyodysenteriae $(11,8 \%)$ e 5 sendo todas da mesma granja $(4,5 \%)$ como $B$. intermedia, 2 amostras foram positivas para ambos os agentes $(1,8 \%)$ e 28 não foram caracterizadas através da qPCR (25,5\%). Não foram observadas alterações histopatológicas no ceco e diferença estatística significativa na contagem de células caliciformes das aves positivas. Conclui-se que a Brachyspira sp. é frequente em granjas de poedeiras e matrizes de corte no Brasil, com especial relevância para a B. intermedia que possui potência patogênico para estas aves.

TERMOS DE INDEXAÇÂO: Brachyspira pilosicoli, Brachyspira hyodysenteriae, Brachyspira intermedia, aves de postura, matrizes de corte, Paraná, isolamento bacteriano, qPCR, aves comerciais, frequência, enteropatogenos, espiroquetose, bacterioses.

\section{INTRODUCTION}

Bacteria of the Brachyspira species can cause enteric diseases, especially in birds and swine, besides that, they have zoonotic feature. Four species of Brachyspira are considered pathogenic to birds, being Brachyspira intermedia, Brachyspira pilosicoli, Brachyspira alvinipulli and Brachyspira hyodysenteriae, and one or more species can be concomitantly involved in the development of diseases (Song \& Hampson 2009, Mappley et al. 2014).

On hens, the Brachyspira sp. is associated with a clinical condition known as avian intestinal spirochetosis (AIS) commonly observed in older birds (Phillips et al. 2005, Medhanie et al. 2013, Mappley et al. 2014). B. intermedia and B. pilosicoli are the main causers (Stephens \& Hampson 2002, Bano et al. 2008), and B. alvinipulli appears in lower frequency (Phillips et al. 2006, Feberwee et al. 2008). The clinical signs include chronic diarrhea, weight loss, low egg productivity, and eggs dirty with feces (Medhanie et al. 2013). Burch et al. (2006) compared the performance of lots with AIS and the standard for the laying lineage and found a $6 \%$ decrease in egg production and an $8.84 \%$ increase in the mortality rate in an untreated lot.

B. hyodysenteriae is associated with the occurrence of severe typhlitis in rheas (Rhea americana) naturally infected, being the same spirochete that causes swine dysentery (Jensen et al. 1996), disease that has been causing major losses in the Brazilian swine culture (Garcia 2015). Hens are natural carriers of this species, but in these birds $B$. hyodysenteriae is apathogenic (Feberwee et al. 2008). Nevertheless, this Brachyspira species has importance in poultry and swine producing regions, as observed by Backhans et al. (2011) Brachyspira sp. can transit between birds, pigs and rodents. All these animals can be colonized from a common environmental source, so rats and mice can act on the transmission of $B$. hyodysenteriae and B. pilosicoli among lots or even granges of different species.

Occurrence of Brachyspira sp. has already been found in poultry-producing countries such as Italy where Brachyspira was $72.4 \%$ in laying granges and $31 \%$ of these samples were pathogenic (Bano et al. 2008). In Australia the prevalence found was $42 \%$ in broilers and $68 \%$ in laying hens (Stephens \& Hampson 2002); and recently in Argentina, 44\% positivity was found in the evaluated laying hens (Illanes et al. 2016).

Due to the lack of data on the occurrence of AIS in Brazil, this study evaluated for the first time the occurrence of Brachyspira sp. in commercial birds and broiler breeders in western Paraná State, through selective anaerobic culture, and isolates were identified using the qPCR technique for B. pilosicoli, B. intermedia and B. hyodysenteriae species.

\section{MATERIALS AND METHODS}

Samples. This study was approved by the Animal Use Ethics Committee of the Pallottine Sector of the "Universidade Federal do Paraná" (UFPR) under the protocol CEUA-Palotina 06/2017. One hundred and ten samples were collected, all in farms located in western Paraná. Forty samples of hens kept in cage were collected from two commercial poultry farms located in the district of Céu Azul, of the Californian style. One of the properties had four floors of cages and the birds were 82 weeks old, the other farm had no fences, only one floor of cages and birds were aged 35 and 40 weeks. This last property had also a pig grange. The other 70 samples were from broiler breeders coming from two breeders that had a rigorous biosafety scheme with separate nuclei and climate-controlled houses with a density of seven birds per $\mathrm{m}^{2}$. Of these, 20 samples were from the Assis Chateaubriand city broiler, divided between two nuclei aged 47 and 59 weeks. The remaining 50 samples were from a Palotina city breeder, divided into five nuclei aged 46, 60, 65 and 67 weeks; one of the nuclei aged 60 weeks had a history of diarrhea at week 46. The birds were randomly selected throughout the house and then necropsied. Cecum segments were collected and immediately packed in an ice-cold isotherm box and sent to the laboratory for bacterial isolation. Cecum fragments were collected and fixed in $10 \%$ buffered formalin and further processed by the routine paraffin embedding technique recommended by Tolosa et al. (2003) for periodic acid-Schiff (PAS) and hematoxylin-eosin (HE) staining.

Bacterial isolation. The protocol for bacterial isolation followed the recommendations by Neves (2012). Feces samples were seeded by plating with Brachyspira sp. (anaerobiosis agar (Neogen Co, MI, USA), $5 \%$ sheep blood, $6.25 \mathrm{mg} / \mu \mathrm{l}$ rifampicin (Sigma-Aldrich Co, MO, USA), $800 \mathrm{mg} / \mu \mathrm{l}$ of spectinomycin (Sigma-Aldrich Co, MO, USA), $25 \mathrm{mg} / \mu \mathrm{l}$ of vancomycin (Sigma-Aldrich Co, MO, USA), $25 \mathrm{mg} / \mu \mathrm{l}$ of colistin (Sigma-Aldrich Co, MO, USA). They were incubated in anaerobiosis jar with an anaerobic atmosphere generated with anaerobiosis media (Anaerobac ${ }^{\circledR}$, Probac of Brazil, São Paulo, Brazil) at $42^{\circ} \mathrm{C}$ for three days or until evidence of hemolysis. The anaerobic environment was confirmed by an anaerobiosis indicator strip (Oxoid Anaerobic Indicator ${ }^{\circledR}$, Thermo Fisher, MA, USA). Growth was considered positive when areas of strong and weak plaque hemolysis were evidenced; it was sometimes accompanied by white millimeter colonies, suggesting Brachyspira sp. These areas and/or colonies were carefully picked using a calibrated loop on anaerobic isolation agar plates (Neogen Co, MI, USA) containing 5\% sheep blood and incubated anaerobically for three days at $37^{\circ} \mathrm{C}$. W. After obtaining Brachyspira sp. these were collected with a calibrated loop and resuspended in $1.5 \mathrm{~mL}$ of fetal bovine serum. This suspension was frozen at $-20^{\circ} \mathrm{C}$ until qPCR was performed.

qPCR (real time polymerase chain reaction). DNA was extracted from all samples that showed growth for Brachyspira sp. 
using QIAamp cador Pathogen Mini Kit ${ }^{\circledR}$ (Qiagen, New York, USA) according to manufacturer's instructions.

Samples were analyzed in a private laboratory using primers described by La et al. (2003) for B. hyodysenteriae and B. pilosicoli, and for $B$. intermedia the sequence described by Phillips et al. (2005). The protocol followed the recommendations of Song \& Hampson (2009).

Histopathology. HE-stained cecum sections were evaluated for possible histological lesions compatible with Brachyspira infection such as inflammatory changes, epithelial erosion, intralesional bacteria, "false brush border" formation, crypt hyperplasia and lymphoid follicle hyperplasia.

PAS and goblet cell count. $5 \mu \mathrm{m}$ thick sections of cecum fragments were subjected to PAS staining to evidence the goblet cells.

For the goblet cell count, the cecum sections were analyzed under the microscope and the number of cells from ten random fields were counted, the marked goblet cells were accounted and from these values an average was obtained according to Gottardo et al. (2016).

Statistical analysis. The averages of bird goblet cells in isolation positive, in isolation positive with confirmation of species by $B$. hyodysenteriae qPCR and in isolation positive with confirmation of species by qPCR for $B$. intermedia were each compared separately with the group negative in bacterial isolation. The chi-square test was performed, considering $\mathrm{p}<0.05$ statistically significant, using SAS 9.0 software.

\section{RESULTS AND DISCUSSION}

One hundred and ten samples were analyzed, 40 from commercial layers and 70 from matrices. Forty-eight samples were positive for Brachyspira sp. in isolation, being positive $47.5 \%$ of the commercial laying hens and $41 \%$ for the matrices, totalizing $43.6 \%$ of the samples. This result was very close to that found by Illanes et al. (2016) in Argentina in laying hens; however, lower than the $68 \%$ found in Australia by Stephens \& Hampson (2002) or the $72.4 \%$ in Italy by Bano et al. (2008).

Between the two pathogenic species that were identified by the qPCR technique, no sample was characterized as Brachyspira pilosicoli, a species of special importance for being zoonotic and already detected in birds in Argentina (Illanes et al. 2016). The birds analyzed were not on the effect of antibiotics such as tiamulin and lincomycin, pointed out by Stephens \& Hampson (2002) as effective against B. intermedia and B. pilosicoli, which could have influenced bacterial isolation. However, the fact that the medium used contains vancomycin could have influenced the non-isolation of B. pilosicoli, as Calderaro et al. (2005) have already pointed it out as a possible growth inhibitor of $B$. pilosicoli in swine. Five samples were identified as $B$. intermedia, all from the same commercial laying hen grange, which corresponded to $10.5 \%$ of Brachyspira isolates, a percentage also lower than that found in Italy by Bano et al. (2008), showing a lower incidence of AIS agents in Brazil. These results are summarized in Table 1.

Among the farms analyzed, only one of commercial posture showed no positive sample of Brachyspira sp. through culture, the birds of this farm were 82 weeks old. Colonization by Brachyspira sp. is significantly larger in older birds, suggesting that after initial contact the bacterial population increases over time (Phillips et al. 2005, Medhanie et al. 2013). Even though the free grange is the one with the older birds analyzed, this may be associated with the good sanitary control measures adopted in the farm, which prevented the agent from entering and spreading.

However, in another commercial broiler farm with 35 and 40 -week-old birds, only one in 20 birds was not positive at the age of 35 weeks. In the study by Medhanie et al. (2013), who assessed risk factors for colonization of Brachyspira sp. in hens, the presence of birds of different ages in the same farm indicates a higher probability of finding positive birds for Brachyspira sp., which could be observed in this farm.

Twenty-eight samples (58.4\%) positive in isolation were not characterized among the three species surveyed; a possible cause is due to the large number of apathogenic Brachyspira species already identified in the bird intestine, including B. innocens, B. murdochii and B. pulli (Feberwee et al. 2008). Among the pathogenic species described in birds, B. alvinipulli is reported in low field frequency, with few isolations and outbreaks reported in the literature (Phillips et al. 2005, Feberwee et al. 2008), not being the target of this work.

In this study, as found by Phillips et al. (2005) and Illanes et al. (2016), there were positive birds raised in the cage system. Since the transmission route of Brachyspira sp. is due to fecal-oral contact, in this type of system birds have less exposure to excreta, which could reduce contamination, but birds can also be exposed to feces through flies and rodents (Medhanie et al. 2013). Among the 48 samples submitted to qPCR, two $(4.1 \%)$, both from a commercial laying farm, presented positive samples for both $B$. hyodesenteriae and $B$. intermedia. On this property, the California-type aviary had no barriers to the entry of wild and domestic animals, and the place had a pig grange.

Colonization by B. hyodysenteriae was found in $15.7 \%$ of the positive laying hen samples and in $35 \%$ of the hens. In hens, the natural colonization by this species had already been verified by Feberwee et al. (2008). Although this species is not associated with the occurrence of AIS, intestinal infection by $B$. hyodysenteriae in swine can cause severe high-impact mucus-hemorrhagic diarrhea called swine

Table 1. Number of positive culture samples for Brachyspira sp. of poultry and commercial breeders and identification of Brachyspira hyodysenteriae, B. pilosicoli and B. intermedia species by qPCR techniques

\begin{tabular}{|c|c|c|c|c|c|c|}
\hline & $\begin{array}{l}\text { Positive by } \\
\text { isolation }\end{array}$ & $\begin{array}{c}\mathrm{qPCR}^{*} \\
\text { B. hyodysenteriae }\end{array}$ & $\begin{array}{c}\text { qPCR* } \\
\text { B. pilosicoli }\end{array}$ & $\begin{array}{c}\mathrm{qPCR}^{*} \\
\text { B. intermedia }\end{array}$ & $\begin{array}{c}\text { qPCR* } \\
\text { B. intermedia+ } \\
\text { B.hyodysenteriae }\end{array}$ & $\begin{array}{c}\text { Not characterized } \\
\text { by qPCR* }\end{array}$ \\
\hline Commercial layers & $19 / 40(47.5 \%)$ & $3 / 19(15.7 \%)$ & $0 / 19(0 \%)$ & $5 / 19(26.3 \%)$ & $2 / 19(10.5 \%)$ & $9 / 19(47.5 \%)$ \\
\hline Commercial layers+Matrix & & $13 / 48(27 \%)$ & $0 / 48(0 \%)$ & $5 / 48(10.5 \%)$ & $2 / 48(4.1 \%)$ & $28 / 48(58.4 \%)$ \\
\hline Total & $48 / 11043.6 \%$ & $13 / 110(11.8 \%)$ & $0 / 110(0 \%)$ & $5 / 110(4.5 \%)$ & $2 / 110(1.8 \%)$ & $28 / 110(25.5 \%)$ \\
\hline
\end{tabular}

* qPCR real time polymerase chain reaction. 
dysentery (Boye et al., 1998), a disease already evident in the region of this study (Garcia 2015). Thus, the positivity of samples for B. hyodysenteriae, $13 \%$ of all birds analyzed, should serve as a warning due to the proximity of swine and poultry granges in regions where agroindustry is prevalent. As verified by Backhans et al. (2011), swine, poultry and rodents may carry the same Brachyspira species and serve as a source of dissemination.

The hemolysis evidenced in the cultures was of strong hemolysis for the 15 samples identified in the qPCR as $B$. hyodysenteriae, a striking feature of the species in the isolation (Mappley et al. 2014). Strong hemolysis was also observed in five samples identified as B. intermedia, which are routinely classified as having poor hemolysis similar to that previously reported by McLaren et al. (1997) in commercial layers such as this study. Among the 28 samples not identified by qPCR, 22 presented poor hemolysis, but six were strongly hemolytic: five from the same matrix nucleus and a commercial laying sample. Strong hemolysis, similar to the decay for $B$. hyodysenteriae, has already been observed in two new species, B. suanatina and B. hampsonii, which have also been identified in swine and wild birds (Råsbäck et al. 2007, Chander et al. 2012).

No histological changes compatible with Brachyspira sp. as verified by Stephens \& Hampson (2002), who evaluated experimentally infected hens were verified. In this study, the lack of lesions was associated with the fact that the analysis was performed several weeks after inoculation and there was time for resolution of possible lesions. Even after recovery and reestablishment of lesions, birds can eliminate Brachyspira for long periods; $B$. intermedia, a pathogenic species isolated in the present study, was already detected in hens' excreta nine months after the challenge (Dwars et al. 1990). In the study by Feberwee et al. (2008), evaluating naturally infected animals, found mild inflammatory alterations, but the animals analyzed by them came from farms that already presented signs compatible with AIS. In addition, the evaluated animals had pre-existing enteritis by other agents, which may be a predisposing factor for the pathogenicity of Brachyspira sp. These conditions were not evidenced in the birds of this work, which may have motivated the lack of histological lesions.

The increase in the number of goblet cells is a change commonly observed in animals infected with Brachyspira sp. (Jensen et al. 1996, Shivaprasad \& Duhamel 2005, Feberwee et al. 2008), but this change was not observed. Isolation negative birds were compared with three groups: isolation positive birds, positive isolated with species confirmation by B. hyodysenteriae and B. intermedia qPCR, in all comparisons goblet cell numbers showed no statistically significant changes. This fact can be explained by the lack of histological lesion in the intestine.

\section{CONCLUSION}

Bacteria of the genus Brachyspira are present in broiler farms and laying hens in Western Paraná, Brazil. Pathogenic strains for poultry such as $B$. intermedia and swine as B. hyodysenteriae can be isolated from healthy poultry excreta, serving as a source of contamination and dissemination of these agents.

Conflict of interest statement.- The authors declare no conflict of interest.

\section{REFERENCES}

Backhans A., Jansson D.S., Aspán A. \& Fellström C. 2011. Typing of Brachyspira spp. from rodents, pigs and chickens on Swedish farms. Vet. Microbiol. 153(1/2):156-162. <http://dx.doi.org/10.1016/j.vetmic.2011.03.023> $<$ PMid:21497461>

Bano L., Merialdi G., Bonilauri P., Dall'anese G., Capello K., Comin D., Cattoli G., Sanguinetti V., Hampson D.J. \& Agnoletti F. 2008. Prevalence, disease associations asn risk factors for colonization with intestinal spirochaetes (Brachyspira spp.) in flocks of laying hens in north-eastern Italy. Avian Pathol. 37(3):281-286.<http://dx.doi.org/10.1080/03079450802043726> <PMid:18568654>

Boye M., Jensen T.K., Møller K., Leser T.D. \& Jorsal S.E. 1998. Specific detection of the genus Serpulina, S. hyodysenteriae and S. pilosicoli in porcine intestines by fluorescent rRNA in situ hybridization. Mol. Cell. Probes 12(5):323-330. <http://dx.doi.org/10.1006/mcpr.1998.0193><PMid:9778458>

Burch D.G., Harding C., Alvarez R. \& Valks M. 2006. Treatment of a field case of avian intestinal spirochaetosis caused by Brachyspira pilosicoli with tiamulin. Avian Pathol. 35(3):211-216. <http://dx.doi. org/10.1080/03079450600711011><PMid:16753612>

Calderaro A., Bommezzadri S., Piccolo G., Zuelli C., Dettori G. \& Chezzi C. 2005. Rapid isolation of Brachyspira hyodysenteriae and Brachyspira pilosicoli from pigs. Vet. Microbiol. 105(3/4):229-234. <http://dx.doi.org/10.1016/j. vetmic.2004.10.021> <PMid:15708820>

Chander Y., Primus A., Oliveira S. \& Gebhart C.J. 2012. Phenotypic and molecular characterization of a novel strongly hemolytic Brachyspira species, provisionally designated Brachyspira hampsonii. J. Vet. Diagn. Invest. 24(5):903-910.<http://dx.doi.org/10.1177/1040638712456975> $<$ PMid:22914820>

Dwars R.M., Smit H.F. \& Davelaar F.G. 1990. Observations on avian intestinal spirochaetosis. Vet. Q. 12(1):51-55. <http://dx.doi.org/10.1080/016521 76.1990.9694242><PMid:2138830>

Feberwee A., Hampson D.J., Phillips N.D., La T., Van Der Heijden H.M.J.F., Wellenberg G.J., Dwars R.M. \& Landman W.J.M. 2008. Identification of Brachyspira hyodysenteriae and other pathogenic Brachyspira Species in chickens from laying flocks with diarrhea or reduced production or both. J. Clin. Microbiol. 46(2):593-600.<http://dx.doi.org/10.1128/JCM.0182907><PMid:18077642>

Garcia E.C. 2015. Frequência de Brachyspira hyodysenteriae e Brachyspira pilosicoli em suínos de terminação na mesorregião oeste do estado do Paraná, Brasil. Master Thesis, Universidade Federal do Paraná, Palotina. 58p.

Gottardo E.T., Prokoski K., Horn D., Viott A.D., Santos T.C. \& Fernandes J.I. 2016. Regeneration of the intestinal mucosa in Eimeria and E. coli challenged broilers supplemented with amino acids. Poultry Sci. 95(5):1056-1065. <http://dx.doi.org/10.3382/ps/pev356><PMid:26846258>

Illanes N.J.V., Tamiozzo P.J., Cabral A., Bertone J., Romanini S., Yaciuk R., Vazquez M. \& Pelliza B.R. 2016. Detección de Brachyspira pilosicoli y otras espécies de Brachyspira en granjas avícolas argentinas. Revta Argent. Micribiol. 48(1):67-70. <http://dx.doi.org/10.1016/j.ram.2015.12.002>

Jensen N.S., Stanton T.B. \& Swayne D.E. 1996. Identification of the swine pathogen Serpulina hyodysenteriae in rheas (Rhea americana). Vet. Microbiol. 52(3/4):259-269. <http://dx.doi.org/10.1016/S0378-1135(96)00076-4> $<$ PMid:8972051>

La T., Phillips N.D. \& Hampson D.J. 2003. Development of a duplex PCR assay for detection of Brachyspira hyodysenteriae and Brachyspira pilosicoli in pigfeces. J. Clin. Microbiol. 41(7):3372-3375. <http://dx.doi.org/10.1128/ JCM.41.7.3372-3375.2003><PMid:12843096>

Mappley L.J., La Ragione R.M. \& Woodward M.J. 2014. Brachyspira and its role in avian intestinal spirochaetosis. Vet. Microbiol. 168(2/4):245-260. <http://dx.doi.org/10.1016/j.vetmic.2013.11.019><PMid:24355534>

McLaren A.J., Trott D.J., Swayne D.E., Oxberry S.L. \& Hampson D.J. 1997. Characterization of intestinal spirochetes colonizing chickens and allocation 
of known pathogenic isolates to three distinct genetic groups. J. Clin. Microbiol. 35(2):412-417. <PMid:9003607>

Medhanie G.A., Mcewen S.A., Weber L., Sanei B., Cooley L., Houghton S., Slavic D. \& Guerin M.T. 2013. Risk factors associated with the colonization of Ontario layer chicken flocks with Brachyspira species. Prev. Vet. Med. 109(3/4):304-311.<http://dx.doi.org/10.1016/j.prevetmed.2012.09.017> $<$ PMid:23182029>

Neves S.M.N. 2012. Avaliação das técnicas de isolamento, reação em cadeia da polimerase e hibridização fluorescente in situ para diagnóstico de Brachyspira sp. em suínos. Master Thesis, Universidade Federal de Minas Gerais, Belo Horizonte. 49p.

Phillips N.D., La T. \& Hampson D.J. 2005. A cross-sectional study to investigate the occurrence and distribution of intestinal spirochaetes (Brachyspira spp.) in three flocks of laying hens. Vet. Microbiol. 105(3/4):189-198. <http://dx.doi.org/10.1016/j.vetmic.2004.10.016><PMid:15708815>

Phillips N.D., La T. \& Hampson D.J. 2006. Development of a two-step nested duplex PCR assay for the rapid detection of Brachyspira pilosicoli and Brachyspira intermedia in chicken faeces. Vet. Microbiol. 116(1/3):239-245. <http://dx.doi.org/10.1016/j.vetmic.2006.03.020><PMid:16677782>
Råsbäck T., Jansson D., Johansson K.-E. \& Fellström C. 2007. A novel enteropathogenic, strongly haemolytic spirochaete isolated from pig and mallard, provisionally designated 'Brachyspira suanatina' sp. nov. Environ. Microbiol. 9(4):983-991.<http://dx.doi.org/10.1111/j.1462-2920.2006.01220. $\mathrm{x}><$ PMid:17359270>

Shivaprasad H.L. \& Duhamel G.E. 2005. Cecal spirochetosis caused by Brachyspira pilosicoli in Commercial Turkeys. Avian Dis. 49(4):609-613. <http://dx.doi.org/10.1637/7383-052005.1><PMid:16405009>

Song Y. \& Hampson D.J. 2009. Development of a multiplex qPCR for detection and quantitation of pathogenic intestinal spirochaetes in the faeces of pigs and chickens. Vet. Microbiol. 137(1/2):129-136. <http://dx.doi. org/10.1016/j.vetmic.2008.12.020> <PMid:19171443>

Stephens C.P. \& Hampson D.J. 2002. Experimental infection of broiler breeder hens with the intestinal spirochaete Brachyspira (Serpulina) pilosicoli causes reduced egg production. Avian Pathol. 31(2):169-175. <http:// dx.doi.org/10.1080/03079450120118667><PMid:12396362>

Tolosa E.M.C., Rodrigues C.J., Behmer O.A. \& Freitas Neto A.G. 2003. Manual de Técnicas para Histologia Normal e Patológica. $2^{\underline{a}}$ ed. Manole, Barueri, p.20-41. 